\title{
Odontoma associated with impacted mandibular canine: surgically guided eruption
}

\author{
Odontoma associado a canino inferior incluso: erupção cirurgicamente guiada
}

\author{
Murilo Maia NASCIMENTO' \\ Carolina Medeiros de ALMEIDA ${ }^{1}$ \\ Cassiano Francisco Weege NONAKA ${ }^{1}$ \\ Tony Santos PEIXOTO' \\ Ana Flávia GRANVILLE-GARCIA ${ }^{1}$ \\ Edja Maria Melo de Brito COSTA'
}

\begin{abstract}
Odontoma is the most common type of odontogenic tumor and is most often diagnosed in the second decade of life. This benign tumor has a slow growth and is asymptomatic, which favors its persistence in the bone until some clinical sign emerges or the tumor or be detected in a routine radiograph. The aim of this case report was to present a clinic case of a 13-year-old male, who presented delayed exfoliation of the mandibular right primary canine. The radiographic exam revealed a radiopaque image in the anterior region of the mandible produced by structures that resembled the formation of teeth surrounded by a radiolucent area. Adjacent to the tumor, the impacted mandibular right canine was identified with deviation of its eruption axis. The clinical diagnosis was compound odontoma. Treatment consisted of the removal of the tumor and the surgically-assisted eruption of the tooth without orthodontic traction. After three years of follow up, the patient has exhibited positive results. It is possible to surgically assist the eruption of an impacted tooth, with a deviated axis, associated with an odontoma through the removal of the tumor and of the physical barrier (ostectomy) without orthodontic traction.
\end{abstract}

Indexing terms: Non-erupted tooth. Odontoma. Oral surgery.

\section{RESUMO}

Os odontomas são considerados os tipos mais comuns de tumores odontogênicos e frequentemente diagnosticados na segunda década de vida. Possuem crescimento lento, comportamento benigno e assintomático, favorecendo sua permanência intraóssea por muito tempo até demonstrarem algum sinal clínico ou serem detectados em radiografias de rotina. O objetivo deste relato foi apresentar um caso clínico de um paciente de 13 anos de idade, sexo masculino, que apresentou atraso na esfoliação do canino decíduo inferior direito. No exame radiográfico, verificou-se uma imagem radiopaca na região anterior da mandíbula, produzida por estruturas que lembravam a formação de dentes, circundada por uma área radiolúcida. Adjacente à lesão, na parte basal, identificou-se a presença do canino permanente inferior direito incluso, apresentando desvio do seu eixo de erupção. O diagnóstico clínico foi definido como odontoma composto. O tratamento consistiu na remoção da lesão e erupção do dente incluso associado, por meio de intervenções cirúrgicas, sem tração ortodôntica, com três anos de acompanhamento e resultados positivos. Existe a possibilidade de erupção cirurgicamente guiada de dente retido, com desvio do seu eixo de erupção e associado à odontoma, através da remoção da lesão e da barreira física (ostectomia) sem tração ortodôntica.

Termos de indexação: Dente não erupcionado. Odontoma. Cirurgia bucal.

\section{INTRODUCTION}

Odontoma is a benign odontogenic tumor pertaining to the group of odontogenic epithelial tumors with the formation of mineralized tissues ${ }^{1-2}$. Despite this, odontomas are clinically considered as tumor-like formations (hamartomas of dental tissues) or developmental anomalies, rather than true odontogenic neoplasms ${ }^{3}$.
Odontoma is commonly asymptomatic and associated with the abnormal eruption of adjacent teeth ${ }^{4}$. Such tumors account for approximately $22 \%$ of all odontogenic tumors 5 and are most often diagnosed in the second decade of life and the most common location is the anterior region of maxilla ${ }^{3}$.

Surgical removal represents the best therapeutic option and the prognosis after treatment is very favorable,

\footnotetext{
${ }^{1}$ Universidade Estadual da Paraíba, Faculdade de Odontologia. Rua Baraúnas, 351, Universitário, 58429-500, Campina Grande, PB, Brasil. Correspondência para / Correspondence to: EMMB COSTA. E-mail: <edjacosta@gmail.com>.
} 
with very low recurrence's incidence ${ }^{6}$.

Studies have reported the occurrence of odontoma associated with impacted teeth, the treatment of which involves the removal of the tumor with or without the impacted tooth, the eruption of which can occur spontaneously or, more frequently, with orthodontic traction ${ }^{2,5-8}$. However, this treatment modality involves the possibility of gingival retraction, causing a difference in the gingival level between the tooth submitted to traction and other teeth ${ }^{9}$ as well as the occurrence of external root resorption due to the induction of forces of inadequate intensity ${ }^{10}$.

This paper presents a clinical case of the surgically assisted eruption of an impacted mandibular canine, with a deviated eruption axis without the need for orthodontic traction, associated with a compound odontoma.

\section{CASE REPORT}

A 13-year-old male was submitted to routine dental treatment, during which the prolonged retention of the mandibular right canine and absence of its permanent successor were observed, with no signs of a convex curve of the cortical bone. The patient reported the absence of pain. The panoramic radiograph revealed a radiopaque image in the region of the mandibular right canine produced by a collection of structures similar to rudimentary teeth surrounded by a radiolucent area of approximately 20 millimeters in circumference. The impacted mandibular right canine was also identified adjacent to the tumor (Figure 1A). The clinical diagnosis was compound odontoma with the indication for surgical treatment and the preservation of the impacted canine.

Surgical treatment was conducted in three phases. Extraction of the primary canine allowed trans-alveolar access for the removal of the tumor through curettage and transalveolar ostectomy was performed to expose the crown of the impacted canine to assist in its eruption. After eight months of clinical and radiographic follow up, healing of the alveolus was observed, with bone formation and slight deviation of the eruption axis of the impacted canine (Figure 1B). The second phase of treatment consisted of the creation of a new surgical shaft with an eruption guide through ostectomy of the healed region. A space retainer was placed between the mandibular right lateral incisor and mandibular right first premolar to impede the movement of these teeth into the empty space and allow the complete eruption of the impacted canine. After another eight-month period, evident progression of the eruption of the canine was noted, along with the formation of a thin layer of healed bone above the tooth (Figure 1C). The third phase of surgical treatment consisted of the creation of a new shaft through ostectomy of this bone layer to the incisal part of the canine.
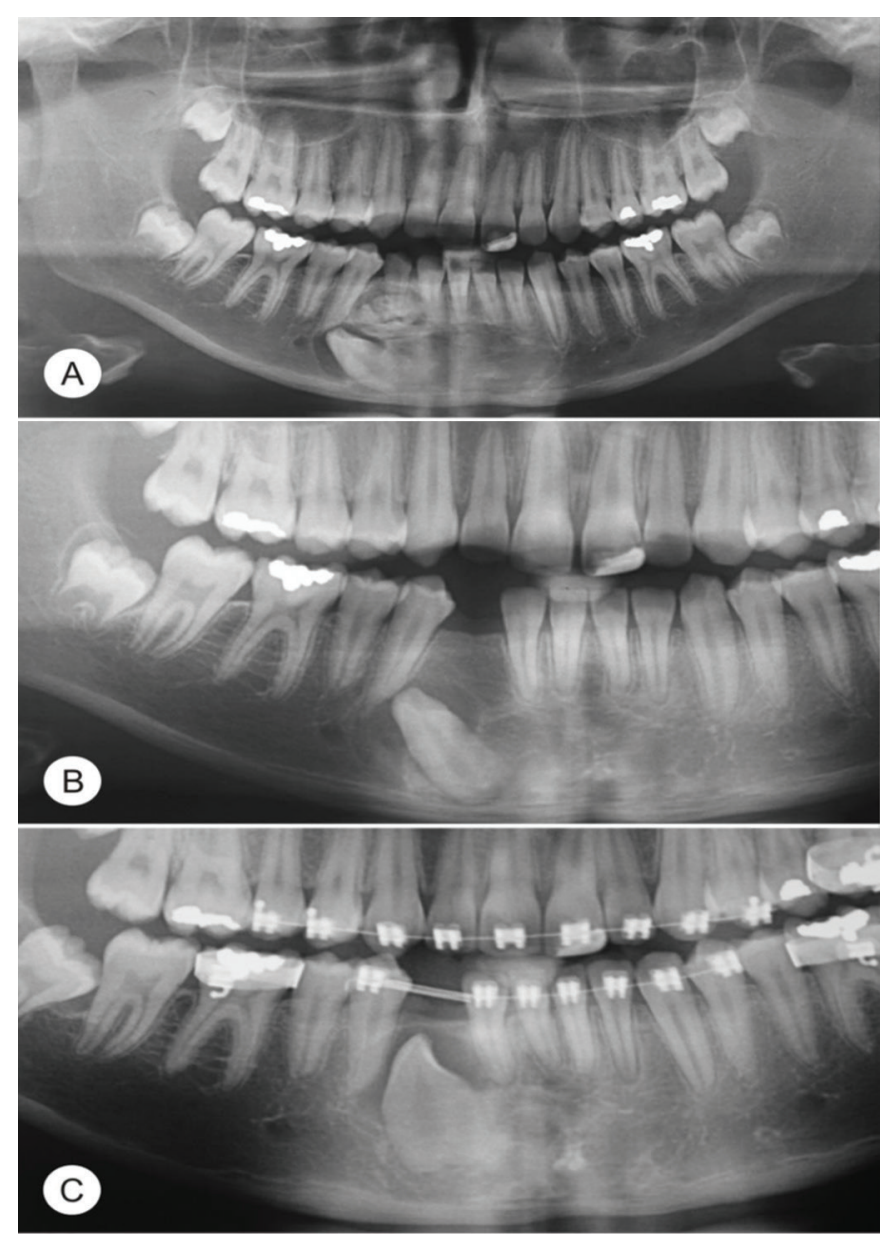

Figure 1. A) Panoramic radiographic showing impacted permanent mandibular right canine with radiopaque image surrounded by radiolucent area; B) Radiographic image 8 months after removal of tumor showing bone healing in region above impacted mandibular right canine; C) Radiographic image 16 months after last session showing space retainer and progressive eruption of impacted mandibular right canine.

Two months later, clinical observation and periapical radiography revealed that the canine was in its proper eruption axis, with the exposure of the incisal third and gyration, with the vestibular face turned toward the distal direction (Figure 2A and 2B). A total of 38 months after the initial intervention, the canine had completely erupted, including orthodontic treatment to correction the gyration (Figure 2C and 2D). 

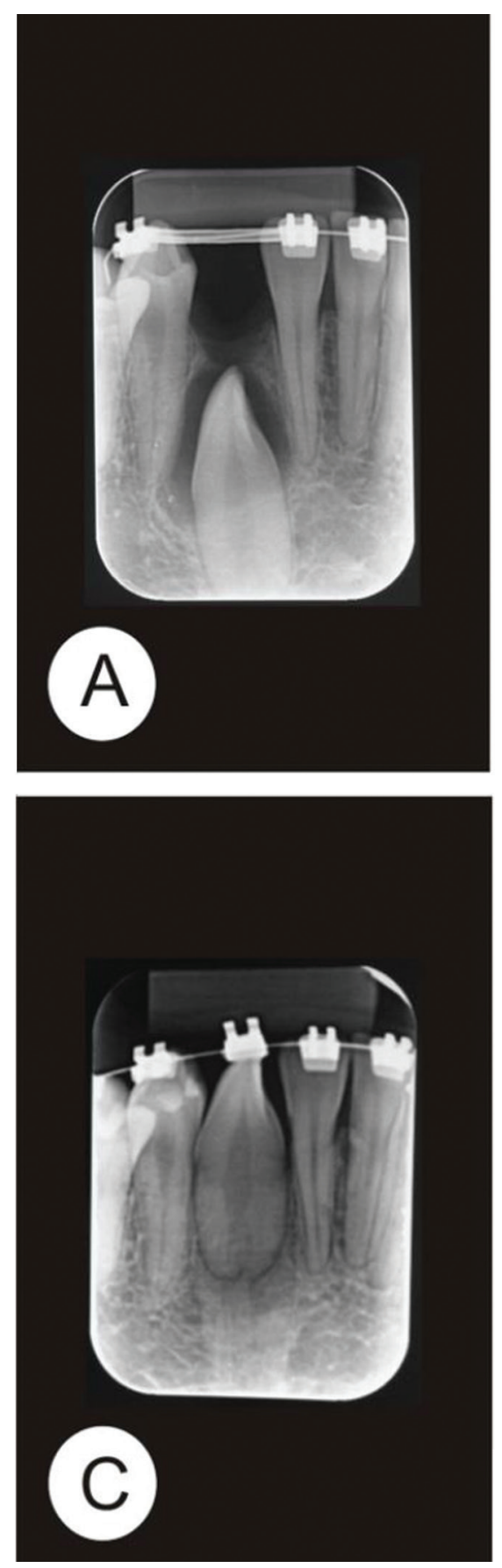

Figure 2. A) Periapical radiograph showing permanent mandibular right canine positioned in proper eruption axis; B) Clinical presence of incisal region of permanent mandibular right canine in eruption; C) Periapical radiograph showing permanent mandibular right canine completely erupted; D) Clinical image of erupted canine.
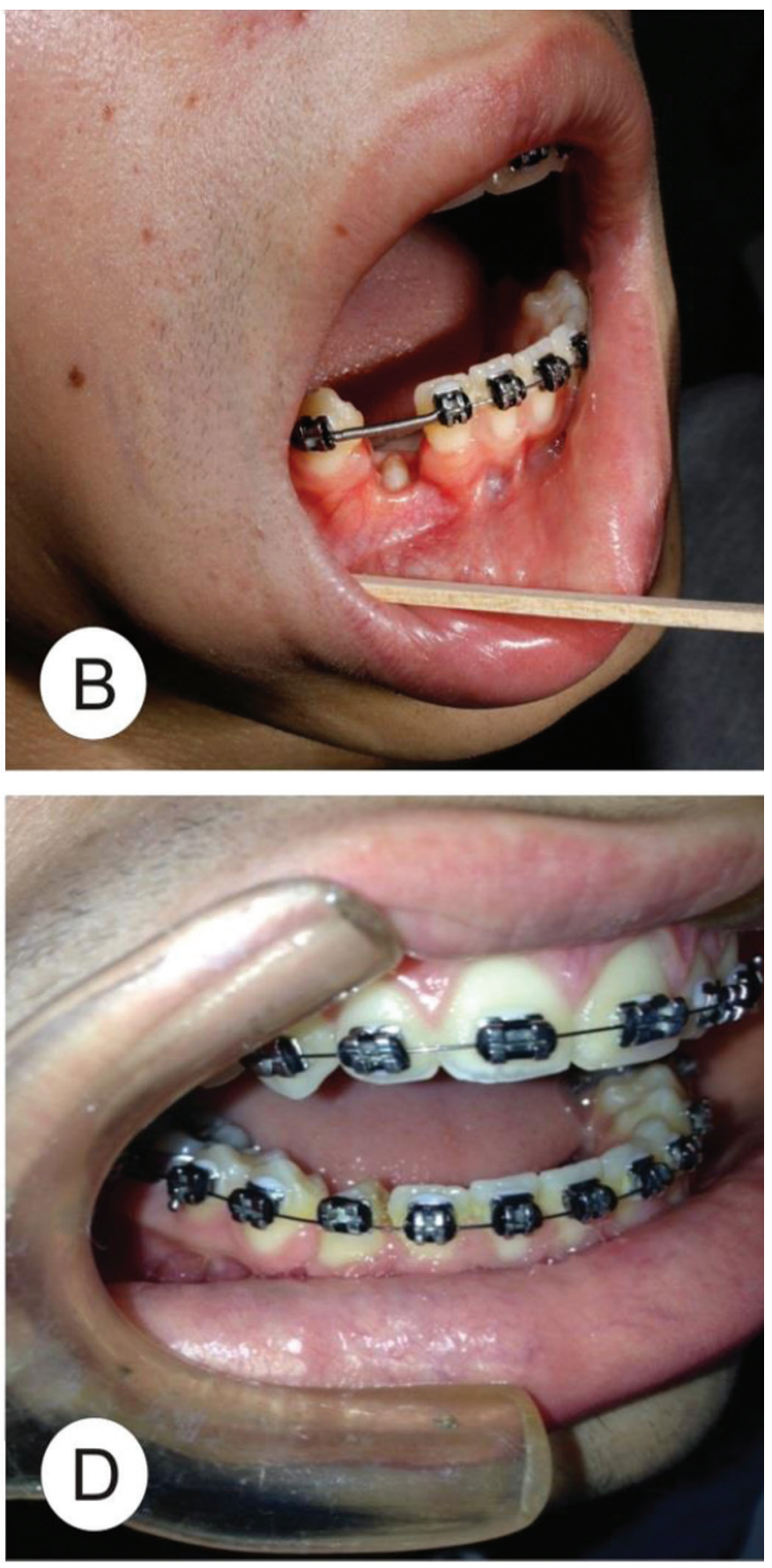

\section{DISCUSSION}

Conservative surgical treatment of an impacted tooth is indicated for young patients when the tooth is in alveolar impaction with the potential for eruption and there is sufficient space for its eruption in the arch. However, one must not expect the spontaneous movement of an impact 
orthodontic traction. Eight months after the removal of the tumor, the eruption of the tooth began. Despite the deviation in its eruption axis, the possibility of spontaneous eruption was considered, which was facilitated by surg ical procedures for the creation of an eruption guide. Thirtyeight months after the first phase of surgical treatment, the complete eruption of the permanent mandibular right canine occurred. The decision to perform access to the tooth included through more surgery was taken in order to monitor its eruptive behavior carefully, accessing the same according to the need, removing as necessary bone formation above the tooth, eliminating any physical barrier that would prevent its eruption.

Odontoma is considered most common form of odontogenic tumor and is comprised of dental tissues (enamel and/or dentin) distributed in a disorderly fashion ${ }^{12}$. A number of etiological factors are attributed to the formation of an odontoma, such as trauma, an inflammatory/infectious process, hereditary anomalies (Gardner's syndrome or Hermann's syndrome) and abnormalities in the genetic components responsible for the control to dental development ${ }^{4}$. In the present case, no clinical factor was identified to explain the appearance of the tumor.

An odontoma is generally asymptomatic and diagnosed in the first two decades of life $^{13}$. In the present report, the tumor was identified due to abnormal exfoliation and eruption of the teeth in the region of the tumor, which is how such tumors are diagnosed in more than half the cases ${ }^{3}$. The literature reports occasional cases involving pain, swelling expansion of the bone cortex and tooth displacement ${ }^{14}$. However, displacement of the permanent canine was only observed in the present case with regard to its eruption axis.

In a study involving 26 cases of odontoma, latrou et al. ${ }^{6}$ identified 16 cases associated with impacted teeth and treatment, in most cases, consisted of the removal of the tumor and traction of the impacted tooth. In only one case, spontaneous eruption of the impacted tooth was reported following the removal of the tumor. Kulkarni et al. ${ }^{5}$ report a similar case.

An et al. ${ }^{3}$ in a retrospective study, evaluated the clinical findings and treatment results for 73 cases of impacted permanent teeth associated with odontomas. Most odontomas (84.9\%) were removed surgically, and the impacted permanent teeth associated with the odontomas were managed by surgical removal (53.2\%), orthodontic treatment $(25.5 \%)$, or surgical repositioning (6.4\%). Twenty-three teeth were saved through orthodontic treatment, surgical repositioning, and normal eruption. All impacted teeth were preserved in those under 9 years old, while all were removed over 30 years old. Only in $7 \%$ of the cases the impacted teeth erupted spontaneously.

Eight of 25 impacted teeth erupted spontaneously after surgical removal of odontomas in the study of Tomizawa et al. ${ }^{15}$. In their study, the patients had been observed more than 3 months after the first removal and then if the impacted teeth had not erupted, surgical exposure of the tooth crown with or without orthodontic traction had been performed.

Although the prognosis of the spontaneous eruption of impacted teeth associated with an odontoma is considered positive following the excision of the tumor ${ }^{16}$, it is generally recommended that the tumor be excised, the impacted tooth be exposed and a bracket be placed for orthodontic traction in a single session to facilitate the eruption of the tooth ${ }^{2,7-8}$. However, this requires the greater removal of bone tissue and the excessive manipulation of the dental follicle during the surgical procedure, which can lead to the risk of external cervical resorption following the traction of the non-erupted tooth ${ }^{8}$. Furthermore, the cost and time for orthodontic traction of an impacted tooth are disadvantages to both the dentist and patient in comparison to the exposure of the impacted tooth without traction, which is a simple, low-cost technique ${ }^{11}$.

\section{CONCLUSION}

The present case demonstrates that it is possible to surgically guide the eruption of an impacted tooth with a deviated axis associated with an odontoma through the removal of the tumor and physical barrier (ostectomy) with positive results and without the need for orthodontic traction.

\section{Collaborators}

TS PEIXOTO was responsible for supplying the data for the research. EMMB COSTA, AF GRANVILLEGARCIA, MM NASCIMENTO, CFW NONAKA and TS PEIXOTO analysed the data and designed the research. CM ALMEIDA e MM NASCIMENTO wrote the manuscript. 


\section{REFERENCES}

1. Barnes L, Eveson JW, Reichart P, Sidransky D. WHO Classification of Tumors: Pathology and Genetics of Head and Neck Tumors. Lyon, France: IARC Press; 2005.

2. Baldawa RS, Khante KC, Kalburge JV, Kasat VO. Orthodontic management of an impacted maxillary incisor due to odontoma. Contemp Clin Dent. 2011;2(1):37-40. doi: 10.4103/0976237X.79312

3. An SY, An CH, Choi KS. Odontoma: a retrospective study of 73 cases. Imaging Sci Dent. 2012;42(2):77-81.

4. Serra-Serra G, Berini-Aytés L, Gay-Escoda C. Erupted odontomas: A report of three cases and review of the literature. Med Oral Patol Oral Cir Bucal. 2009;14(6):299-303.

5. Kulkarni VK, Vanka A, Shashikiran ND. Compound odontoma associated with an unerupted rotated and dilacerated maxillary central incisor. Contemp Clin Dent. 2011;2(3):218-21. doi: 10.4103/0976-237X.86466

6. Iatrou I, Vardas E, Theologie-Lygidakis N, Leventis M. A retrospective analysis of the characteristics, treatment and follow-up of 26 odontomas in greek children. J Oral Sci. 2011;52(3):439-47.

7. Salgado H, Mesquita P. Compound odontoma: case report. Rev Port Estomatol Cir Maxilofac. 2013;54:161-5. doi: 10.1016/j. rpemd.2012.11.001

8. Sreedharan S, Krishnan IS. Compound odontoma associated with impacted maxillary incisors. J Indian Soc Pedod Prev Dent. 2012;30(3):275-8. doi: 10.4103/0970-4388.105025. PMID:23263436

9. Hattab FN, Yassin OM, Rawashdeh MA. Supernumerary teeth: report of three cases and review of the literature. ASDC J Dent Child. 1994;61(5-6):382-93
10. Capelozza Filho L, Consolaro A, Cardoso MA, Siqueira DF. Enamel drilling for canine traction: advantages, disadvantages, description of surgical technique and biomechanics. Dental Press J Orthod. 2011;16(5):172-205. doi: 10.1590/S217694512011000500024

11. Gaetti-Jardim EC, Faria KM, Santiago Junior JF, GaettiJardim Junior EG, Saad Neto $M$, et al. Condutas terapêuticas para caninos inclusos. UNOPAR Cient Ciênc Biol Saúde. 2012;14(1):51-6.

12. Nelson BL, Thompson LDR. Compound odontoma. Head Neck Pathol. 2010;4(4):290-1. doi: 10.1007/s12105-010-0186-2

13. Nagaraj K, Upadhyay M, Yadav S. Impacted maxillary central incisor, canine, and second molar with 2 supernumerary teeth and an odontoma. Am J Orthod Dentofacial Orthop. 2009;135(3):390-9. doi: 10.1016/j.ajodo.2006.12.023

14. Chandra S, Bagewadi A, Keluskar V, Sah K. Compound composite odontome erupting into the oral cavity: A rare entity. Contemp Clin Dent. 2010;2(1):123-6. doi: 10.4103/0976237X.68591

15. Tomizawa M, Otsuka $Y$, Noda T. Clinical observations of odontomas in Japanese children: 39 cases including one recurrent case. Int J Paediatr Dent. 2005;15:37-43.

16. Troeltzsch $M$, Liedtke J, Troeltzsch $V$, Frankenberger R, Steiner T. Odontoma-associated tooth impaction: accurate diagnosis with simple methods? Case report and literature review. J Oral Maxillofac Surg. 2012;70(10):516-20. doi: 10.1016/j. joms.2012.05.030
Received on: 25/6/2015 Final version resubmitted on: 5/11/2015 Approved on:16/12/2015 